Szymon Piotr Dąbrowski

Uniwersytet Śląski w Katowicach szymon.piotr.dabrowski@gmail.com

\title{
Nieznane wiersze pochwalne na cześć Elżbiety z Branickich Sapieżyny i jej najbliższych krewnych
}

\section{Abstract \\ Unknown panegyric verses in honour of Elżbieta z Branickich Spieżyna and her closest relatives}

The aim of this paper is to present a critical edition of two, to-date unknown eulogies written to honour Elżbieta $\mathrm{z}$ Branickich Sapieżyna and members of her closest family: her son Kazimierz Nestor Sapieha, a general in the Lithuanian army, and her brother Franciszek Ksawery Branicki, the Great Crown Hetman. The two texts were edited according to rules based on solutions applied in the anthology: Wiersze imieninowe poetów $z$ drugiej połowy XVIII wieku (introduction, selection of texts and ed. by B. Wolska, B. Mazurkowa, T. Chachulski, Warsaw 2011). The poems published here are prefaced with an introduction briefly sketching the subject scope of literary research on Elżbieta's portraits (both pamphlet and laudatory ones). The circumstances in which they were written, chief eulogic motives included, and the genre shape of the presented eulogies are discussed. They are also provided with a commentary that explains the meaning of selected words and phrases, and provides information on the key contexts: political, biographical, mythological and biblical.

The first text is an anonymous gift verse entitled: Do Jaśnie Oświeconej księżnej Jejmości Elżbiety z Branickich Sapieżyny, wojewodzicowej mścisławskiej, $w$ dzień imienin 19 Novembris 1784 w Prenach (To her brightly enlightened grace, Elżbieta z Branickich Sapieżyna, wife of the Mścisław Voivode, on her namesday (November 
19th 1784) in Preny). The only known copy of the print is kept in the collection of the National Library in Poland under the reference number XVIII 2.7409. The eulogy was written for Elżbieta's first stay in that Lithuanian town in mid-November 1784. This laudatory composition presents her as a remarkable personage delighting the inhabitants of Preny as well as a model patriot who excellently prepared her son for the service for the country. It contains frequent references to the custom of dedicating poetic gifts called bouquets (Pl. bukiet), a popular act in the occasional poetry of the second half of the 18th century. The text also bears signs of high occasional ode poetics.

The other work is a collection of four poems authored by Wojciech Zacharkiewicz, a little known publicist and poet, active between 1788 and 1793. The only known copy of the print is kept in the collection of the University of Warsaw Library under reference number 4.20.1.557. The elaborate title indicates that the cycle is a Gift from the citizens' hearts... dedicated to the Sapieha family on the occasion of Franciszek Ksawery Branicki's arrival at a Sejm meeting in Warsaw (December 17th 1788) and the election of Kazimierz Nestor Sapieha to the post of Marshal of the Sejm Confederation (October 7th 1788). Each of the poems in the collection is directed at a different person and presents their profile. In the first piece, the poet addressed the hetman and presented a portrait of an excellent commander; in the second, he emphasized the patriotic and citizenly comportment of the voivode's wife; and in the third, he introduced the newly elected marshal as an unparalleled orator. The fourth poem supplements the whole with assertions of everlasting fame of the enlisted virtues and achievements of the notables.

The air of general reverence created here; the instrumental reference to civic and patriotic issues; and the praise of harmful political actions of magnates, bestow a distinct imprint of panegyrism on both texts discussed.

Key words: occasional political poetry, panegyric poems from the second half of the 18th century, panegyric, Elżbieta z Branickich Sapieżyna, Kazimierz Nestor Sapieha, Franciszek Ksawery Branicki 


\section{Wprowadzenie ${ }^{1}$}

Spośród literackich portretów kobiet utrwalonych w piśmiennictwie politycznym drugiej połowy XVIII wieku wyróżniają się bez wątpienia pamfletowe wizerunki Elżbiety z Branickich Sapieżyny (ok. 1734-1800) ${ }^{2}$ z okresu Sejmu Wielkiego ${ }^{3}$. Jedna z najbardziej aktywnych na scenie publicznej arystokratek doby stanisławowskiej, wdowa po Janie, wojewodzicu mścisławskim (zmarł w 1757 roku) była krytykowana już wcześniej - począwszy od czasów zrywu barskiego $^{4}$, gdy dostrzeżono jej intymne kontakty i polityczne związki ze znienawidzonym przez konfederatów królem Stanisławem Augustem $^{5}$. W odróżnieniu od wcześniejszych ataków utwory stworzone w trakcie czteroletnich obrad sejmowych, zazwyczaj łączone z piórem Franciszka Zabłockiego ${ }^{6}$, odznaczają się ciężarem i różnorodnością oskarżeń, a także wielostronnością technik, które służy-

1 Obserwacje i wnioski poprzedzające tę edycję zwięźle przywołują i dopełniają uwagi zawarte w pracy: S.P. Dąbrowski, Wiersze pochwalne na cześć Elżbiety z Branickich Sapieżyny $i$ jej najbliższych krewnych, „Acta Universitatis Lodziensis. Folia Litteraria Polonica" (2016); w druku.

2 M. Czeppe, Sapieżyna z Branickich Elżbieta, w: Polski słownik biograficzny (dalej: PSB), t. 35, Warszawa 1994, s. 163-167.

3 W. Woźnowski, Pamflet obyczajowy w czasach Stanisława Augusta, Wrocław 1973, s. 113-115; S.P. Dąbrowski, Portrety Elżbiety z Branickich Sapieżyny w paszkwilach obyczajowych i politycznych, w: Codzienność i niecodzienność oświeconych, [cz.] 2: W rezydencji, w podróży i na scenie publicznej, red. B. Mazurkowa, z udziałem M. Marcinkowskiej i S.P. Dąbrowskiego, Katowice 2013, s. 139-152; idem, Uwagi o „Porankach kodeńskich” Ignacego Potockiego, „Wschodni Rocznik Humanistyczny" 10 (2014), s. 189-198.

4 W. Woźnowski, Pamflet obyczajowy..., s. 57-58, 110; K. Maksimowicz, Portretowy soterion i jego kulisy: Powinszowanie księżnie Elżbiecie z Branickich Sapieżyn<ie> szczęśliwego do zdrowia powrócenia, w: Czytanie Naruszewicza, [cz.] 1, red. B. Wolska, T. Kostkiewiczowa, B. Mazurkowa, Warszawa 2015, s. 289.

5 A. Norkowska, Wizerunki władcy. Stanisław August Poniatowski w poezji okolicznościowej (1764-1795), Kraków 2006, s. 251-304.

6 R. Kaleta, O twórczości satyrycznej Franciszka Zabłockiego w okresie Sejmu Czteroletniego, w: idem, Oświeceni $i$ sentymentalni. Studia nad literatura i życiem 
ły wyeksponowaniu wad księżny i zdemaskowaniu jej poczynań. $\mathrm{W}$ rozpowszechnianych anonimowo wierszach ${ }^{7}$ wykreowano bowiem sugestywny konterfekt starej, brzydkiej i złośliwej rozpustnicy uwielbiającej intrygi niebezpieczne dla rodzimej wspólnoty. Wbrew niesprawiedliwym sądom paszkwilantów księżna była również adresatką i bohaterką kilku utworów laudacyjnych, co nie może zaskakiwać w kontekście niesłabnącej wówczas popularności okoliczościowych pochwał i powinszowań. Powodzenie tekstów stanowiących ozdobę i pamiątkę różnorodnych wydarzeń życia prywatnego i publicznego utrzymywało się - jak wiadomo - mimo kampanii zainicjowanej przez oświeceniowych literatów przeciwko dziełom, które ich zdaniem naznaczone były pochlebstwem sprzecznym z normami moralnymi i kanonami estetycznymi ${ }^{8}$.

Dotychczas badacze poświęcali niewiele uwagi pochwałom, jakie do Elżbiety Sapieżyny okazjonalnie kierowali twórcy - zazwyczaj mało znani i utalentowani. Wyjątek stanowi tu soterion, który najpewniej jesienią 1770 roku wyszedł spod pióra Adama Naruszewicza ${ }^{9}$. W tym przypadku jednak źródłem namysłu historyków literatury była raczej chęć wnikliwego zbadania imponującego dorobku nadwornego poety Stanisława Augusta, a nie wysoka ocena walo-

w Polsce $w$ okresie trzech rozbiorów, Wrocław 1971, s. 542-596; K. Maksimowicz, Poezja polityczna a Sejm Czteroletni, Gdańsk 2000, s. 5-11, 13-14.

7 K. Maksimowicz, Sposoby rozpowszechniania wierszy polityczno-okolicznościowych $w$ dobie Sejmu Wielkiego i konfederacji targowickiej, w: Byle w ludziach światło było... Księga pamiątkowa ku czci Profesora Wacława Woźnowskiego w dziesiątą rocznicę jego śmierci, red. G. Zając, Kraków 2012, s. 181-191.

8 B. Mazurkowa, Problem i przejawy panegiryzmu w poezji okolicznościowej drugiej połowy XVIII wieku, w: Panegiryk jako element życia literackiego doby staropolskiej i oświeceniowej, red. M. Sulejewicz-Nowicka, Z. Gruszka, wstęp M. Wichowa, Łódź 2013, s. 255-274.

9 A. Naruszewicz, Powinszowanie księżnie Elżbiecie z Branickich Sapieżyn<ie> szczęśliwego do zdrowia powrócenia, w: idem, Poezje zebrane, t. 1, wyd. B. Wolska, Warszawa 2005, s. 170-172 (utwór), s. 231 (komentarz edytorski), s. 312-313 (objaśnienia); K. Maksimowicz, Portretowy soterion..., , s. 283-287. 
rów tego powinszowania ${ }^{10}$. Źródeł nikłego zainteresowania badaczy utworami na część księżny należy upatrywać w kilku przyczynach. Poza niewielką wartością artystyczną omawianych tekstów pewną rolę mogło odegrać uproszczone postrzeganie okazjonalnych laudacji jako niewiele wartych wiązanek komplementów, których nadrzędnym celem było schlebianie możnym adresatom $\mathrm{w}$ nadziei na korzyści materialne ${ }^{11}$. Negatywne oceny tych utworów dodatkowo pogłębiały schetmatyczne sądy historyków na temat charakteru i poczynań arystokratki. Badacze bowiem zbyt często zawierzali oskarżeniom sformułowanym przez poetów stanisławowskich, kreując tym samym „czarną legendę" wojewodzicowej. Ponadto okolicznościowe laudacje, na które dotychczas zwracano uwagę, w większości powstały z okazji imienin, stąd historycy - zainteresowani przede wszystkim wpływem księżny na życie publiczne - zapewne nie postrzegali tych wierszy jako godnych uwagi źródeł informacji związanych z jej działalnością polityczną.

Pochwalne dzieła zasługują jednak na pełniejszy ogląd, ponieważ są interesującymi poświadczeniami literackich zwyczajów i moralnych upodobań epoki, a także stanowią swoisty komentarz do poczynań wojewodzicowej; komentarz, który zazwyczaj - choć nie zawsze w sposób łatwo uchwytny - był związany z sytuacją wewnętrzną Rzeczypospolitej. Z tych powodów niniejsza edycja udostępnia czytelnikom dwa dotychczas nieznane utwory stworzone

10 Utwór skierowany do wojewodzicowej nosi co prawda wyraźne piętno znakomitych umiejętności twórczych, jednak z pewnością nie należy do najbardziej wartościowych liryków okolicznościowych Naruszewicza. Na temat tej gałęzi dorobku pińskiego poety zob. m.in. prace Barbary Wolskiej: Poezja pochwalna i panegiryczna Adama Naruszewicza. Pochwały osobistości publicznych i osób prywatnych, w: Panegiryk jako element życia literackiego..., s. 165-205; Poezja pochwalna i panegiryczna Adama Naruszewicza. Pochwały władcy, w: Byle w ludziach światło było..., s. 59-376; Ogólne uwagi o twórczości okolicznościowej Adama Naruszewicza. Wiersze podarunkowe i bukiety, „Prace Polonistyczne” 59 (2004): Tobie - teraz. W kręgu literackich ofiarowań, s. 123-174.

11 J. Niedźwiedź, Nieśmiertelne teatra sławy. Teoria i praktyka twórczości panegirycznej na Litwie w XVII i XVIII w., Kraków 2003, s. 11-18. 
w latach osiemdziesiątych XVIII wieku na cześć Elżbiety Sapieżyny i jej najbliższych krewnych - syna Kazimierza Nestora Sapiehy, generała artylerii litewskiej i brata Franciszka Ksawerego Branickiego, hetmana wielkiego koronnego. Jak dotychczas odnaleziono wyłącznie pojedyncze egzemplarze każdego z druków, które stanowią podstawę obecnego wydania.

Pierwszy utwór to anonimowy wiersz podarunkowy skierowany: Do Jaśnie Oświeconej księżnej Jejmości Elżbiety z Branickich Sapie$\dot{z} y n y$, wojewodzicowej $m<s ́$ sisławskiej, $w$ dzień imienin 19 Novembris $1784 w$ Prenach. Druk ten nie jest rejestrowany w kompendium Estreicherów i bibliografii „Nowy Korbut”, a jedyny znany egzemplarz dzieła znajduje się w zbiorach Biblioteki Narodowej, opatrzony sygnaturą XVIII 2.7049. Pochwalna kompozycja powstała w związku z pierwszą wizytą księżny w litewskiej miejscowości. Magnatka wyruszyła tam z Grodna po zakończeniu prac sejmu 13 listopada 1784 roku. Nie jest zupełnie jasne, jak długo trwał pobyt w Prenach i jaki był jego cel. W wiadomości wysłanej wówczas do kanclerza wielkiego koronnego i biskupa poznańskiego Antoniego Onufrego Okęckiego arystokratka pisała co prawda o krótkim, kilkudniowym czasie wytchnienia „po trudach sejmowych"12, lecz nie można wykluczyć, że jej podróż była również związana z interesami syna. Kazimierz Nestor piastował bowiem urząd miejscowego starosty, który przejął dwa lata wcześniej, po śmierci Michała Butlera, poprzedniego posesora tych dóbr ${ }^{13}$. Nie jest również pewne, czy księżna przebywała w Prenach w dniu imienin, choć taki wniosek nasuwa lektura formuły tytułowej i pewnych wzmianek zamieszczonych w wierszu (zob. w. 5, 12, 35-38, 40) ${ }^{14}$.

12 E. Sapieżyna do A.O. Okęckiego, Olita, 18 listopada 1784, w: Korrespondenz der Fürsten Sapieha. 1709-1798, Archiwum Główne Akt Dawnych, Archiwum Komierowskich, rkps 12/12, s. 173.

13 Ł. Kądziela, Sapieha Kazimierz Nestor, w: PSB, t. 35, Warszawa 1994, s. 53.

14 Zarówno wskazania zawarte w tytule, zgodnie z którymi utwór został podarowany księżnie „w dzień imienin [...] w Prenach”, jak i umieszczone w wierszu apostrofy sugerujące obecność magnatki w momencie podarowania druku nie prze- 
Twórca nadał imieninowemu powinszowaniu charakter hołdu składanego solenizantce w imieniu członków preńskiej wspólnoty. Utwór otwiera refleksja poświęcona oznakom prawdziwej wielkości, a nadrzędną tezą jest tam przekonanie, że do atrybutów wybitnych jednostek należą walory rozumu i ducha, a także wola pracy na rzecz zbiorowości. W dalszej partii pochwalnych rozważań nie pominięto konwencjonalnych komplementów, nadmieniając o majątku, szlachetnym urodzeniu i znakomitym rodowodzie. Zaszczyty te nie są jednak najcenniejszą częścią przybliżanego ideału. W tym ujęciu księżna naturalnie została zaprezentowana jako żywy przykład kreślonego wzoru. Jej sylwetkę dopełniają pochwały eksponujące patriotyczną i obywatelską postawę arystokratki, którym towarzyszą komplementy pod adresem Kazimierza Nestora. Portret generała artylerii litewskiej przedstawia uzdolnionego statystę doskonale przygotowanego przez matkę do działalności publicznej. Całość dopełnia prośba o łaskawe przyjęcie powinszowania oraz życzenia wielu lat życia. Ukształtowanie toku wypowiedzi, której zretoryzowany charakter nadają wielokrotnie stosowane apostrofy, inwersje i wykrzyknienia, zbliża wiersz do poetyki wysokiej ody okolicznościowej ${ }^{15}$. Wskazane w utworze zalety i osiągnięcia księżny oraz jej syna są tam nazywane bukietami podarowanymi arystokratce z okazji dorocznego święta, a także w związku z jej wizytą w Prenach. Takie ujęcie stanowi nawiązanie do motywu rozpowszechnionego w poezji okolicznościowej czasów stanisławowskich, gdy wiersze tworzone z okazji imienin lub urodzin często określano właśnie mianem bukietów. Nazwa utworu ma w tym kontekście sens metaforyczny, odnosi się

sądzają, że faktycznie przebywała ona 19 listopada 1784 roku w litewskiej miejscowości. Por. obserwacje dotyczące relacji między tytulaturą imieninowych wierszy a czasem i kulisami ich napisania, publikacji oraz ofiarowania: B. Wolska, B. Mazurkowa, T. Chachulski, Oświeceniowa poezja imieninowa, w: Wiersze imieninowe poetów z drugiej połowy XVIII wieku, wstęp, wybór i oprac. B. Wolska, B. Mazurkowa, T. Chachulski, Warszawa 2011, s. 30-38.

15 T. Kostkiewiczowa, Oda, w: Słownik literatury polskiego oświecenia, red. T. Kostkiewiczowa, wyd. 4, Wrocław 2006, s. 324-326. 
bowiem do „wiązanki” splecionej nie z prawdziwych kwiatów, lecz $\mathrm{z}$ zalet i osiągnięć chwalonych osób ${ }^{16}$. Ponadto stworzona w wierszu podniosła aura zasłużonego hołdu preńskich obywateli dla cnót i dokonań arystokratki oraz jej syna, jak również powierzchowane ujęcie tematyki obywatelskiej i patriotycznej nadają temu powinszowaniu znamiona panegiryku.

Drugi utwór to zbiór czterech wierszy pochwalnych, który został objęty wspólnym tytułem określającym poetycki cykl mianem Ofiary serc obywatelskich narodu polskiego i W[ielkiego] Ks[ięstwa] Lit [ewskiego]... złożonej domowi Sapiehów przez „wdzięcznego tej famili<i> patriotę". Pod owym określeniem skrył się Wojciech Zacharkiewicz, rejent ziemski brzeskokujawski, a także publicysta i wierszopis aktywny w latach 1788-1793. Jedyny znany egzemplarz druku zachował się w zasobach Biblioteki Uniwersytetu Warszawskiego, a oznaczony został sygnaturą 4.20.1.557. Wolant ten jest notowany przez kompendium Estreicherów, jak i w bibliografii Nowy Korbut $^{17}$. Jak wskazano w obszernej formule tytułowej laudacja została skomponowana dla upamiętnienia dwóch wydarzeń z początków czteroletnich obrad: przyjazdu do Warszawy hetmana wielkiego koronnego Franciszka Ksawerego Branickiego oraz wyboru Kazimierza Nestora Sapiehy na stanowisko marszałka z ramienia Litwy niedawno zawiązanej konfederacji sejmowej. Każda z wierszowanych pochwał ma innego adresata indywidualnego bądź zbiorowego. W pierwszym utworze jest nim Franciszek Ksawery Branicki, w następnym - Elżbieta Sapieżyna, w trzecim - Kazimierz Nestor Sapieha, natomiast w czwartym i ostatnim - troje wskazanych ary-

16 B. Wolska, B. Mazurkowa, T. Chachulski, Oświeceniowa poezja imieninowa..., s. 20-25, 39-53.

${ }_{17}$ K. Estreicher, Bibliografia polska, cz. 3: Stulecie XV-XVIII w uktadzie abecadłowym, t. 23 (34), z. 1: Z-Załuski, do druku przygotował K. Estreicher, Kraków 1951, s. 63; Bibliografia literatury polskiej „Nowy Korbut”, t. 6, cz. 1: Oświecenie. Hasła osobowe P-Ż. Addenda A-O, oprac. E. Aleksandrowska z zespołem, red. tomu do r. 1958 T. Mikulski, [Warszawa] 1970, s. 510; t. 6, cz. 2: Oświecenie. Uzupełnienia, indeksy, oprac. E. Aleksandrowska z zespołem, [Warszawa] 1972, s. 143. 
stokratów. Dodatkowe informacje na temat okoliczności powstania pochwalnego zbioru przynosi kilkanaście początkowych wersów pierwszego tekstu. Mowa tam o radości z tego, że „nieba sprowadziły” (w. 2) hetmana do stolicy, a szczególna uwaga została poświęcona odrzuceniu złośliwej plotki, w myśl której dostojnik miał nigdy nie zjawić się na obradach sejmowych. Źródłem kontrowersji narosłych wokół ówczesnych poczynań Branickiego był wyjątkowo późny przyjazd magnata, stanął on bowiem w Warszawie dopiero 17 grudnia ${ }^{18}$, a więc ponad dwa miesiące po rozpoczęciu prac zgromadzonych stanów. Wcześniej przebywał pod Oczakowem u boku swego rosyjskiego protektora, Gregorija Potiomkina, czekając na zdobycie tej osmańskiej fortecy przez wojska carskie. Postępowanie to wzbudzało wówczas zrozumiałą konsternację, a nawet oburzenie części opinii publicznej.

Pochwalny wizerunek hetmana wskazuje cechy pożądane w charakterze i zachowaniu zwierzchnika wojsk - prawość, męstwo, umiejętność trafnej oceny własnych zdolności, wiarę we współobywateli, umiłowanie rodzinnego kraju i wrogość wobec jego zdrajców. Natomiast portret jego siostry nakreślony w drugim utworze cyklu prezentuje wzór szlachetnie urodzonej patriotki i obywatelki. Stąd poeta wyróżnił arystokratkę ze względu na zaszczytne rodowe koligacje, szczególnie natomiast z powodu urodzenia i wychowania syna, który wyrósł na męża stanu. Ponadto chwalił księżnę za inne zalety - cnotę, duszę i rozum, dość ogólnie wspominając o jej czynach i dziełach. Z kolei konterfekt siostrzeńca Branickiego wykreowany w trzecim utworze zbioru przybliża ideał uwielbianego przez obywateli statysty i utalentowanego mówcy, którego reputacja przewyższa sławę innych zasłużonych członków litewskiego rodu. Owe katalogi cech tworzą całość - jak wiadomo - dość odległą od wiernego portretu. Ujęcie Zacharkiewicza w sposób szczególnie wyraźny nabiera znamion pochlebstwa wówczas, gdy nawiązuje do tradycji kultury antyku. I tak hetman został nazwany „płodem Achillesa”, księżna uhonorowana

18 „Gazeta Warszawska” 102 (1788), k. [1]r. 
tytułem „matki ojczyzny”, natomiast zalety i osiągnięcia jej syna zarówno przeszłe, jak i przyszłe - miały się według poety stać przedmiotem pochwalnych śpiewów Apollina i muz. Ponadto laudacyjny wydźwięk utworu wzmacniają częste zapewnienia o powszechnym uwielbieniu obywateli i sławie towarzyszącej poczynaniom arystokratów; zapewnienia, które - co warto podkreślić - nie służą wyłącznie pochwale. Ich dodatkowym celem jest bowiem dyskretne wyrażenie sugestii, że szacunek i podziw współziomków zobowiązuje magnatów do określonych poczynań. W związku z tym w wierszach adresowanych do Branickiego i Sapiehy, a więc polityków, którzy mieli przemożny wpływ na prace sejmu, Zacharkiewicz wyraźnie podkreślił, że powinni oni nie tylko dochować wierności wyznawanym wartościom, lecz także podjąć starania na rzecz mieszkańców ziem zagarniętych w trakcie pierwszego rozbioru. Całość dopełnia czwarta część cyklu, w której twórca wprowadził ostatni zbiór komplementów, powtarzając deklaracje na temat nieprzemijającej sławy, zalet i osiągnięć trojga arystokratów, przypominając im o konieczności pracy na rzecz ojczyzny i w końcu zamykając pochwalny utwór prośbą, by zachowali jego osobę w łaskawej pamięci.

Obydwa prezentowane teksty, zarówno preński utwór podarunkowy, jak i portretowy cykl, mają wyraźnie klientarny charakter. Oznacza to, że przybliżane ujęcia eksponują patriotyczne i obywatelskie konteksty laudacji nie po to, by podjąć refleksję poświęconą ideałom i problemom rodzimej wspólnoty, lecz wyłącznie w celu wzmocnienia pochwalnej wymowy całości lub ewentualnie (jak w przypadku dzieła Zacharkiewicza) dla uwiarygodnienia aktywności członków stronnictwa, w którego kręgu być może zamówiono wiersze. Wykreowane portrety Elżbiety Sapieżyny są również pokłosiem zmian, jakim podlegało postrzeganie roli kobiet w życiu prywatnym i na scenie publicznej czasów stanisławowskich. W efekcie dramatycznej sytuacji Rzeczypospolitej, której to sytuacji szczególnie boleśnie doświadczono w dobie pierwszego rozbioru, rozpoczął kształtować się i upowszachniać wzór gorliwej patriotki, która pamiętając o obywatelskich tradycjach kraju, swym postępowaniem 
dąży do rozbudzenia miłości ojczyzny wśród członków własnej rodziny i w gronie współobywateli ${ }^{19}$.

Publikowane teksty zostały poddane transkrypcji. Zmodernizowano interpunkcję i zgodnie $\mathrm{z}$ obowiązującą normą znacznie ograniczono użycie wielkich liter (Rodu, Bogactwa, Domu i Imienia $\rightarrow$ rodu, bogactwa, domu i imienia; Narod $\rightarrow$ naród; Wielkiey Matki $\rightarrow$ wielkiej matki; Hetmanie Wielki, Wielkoduszny $\rightarrow$ hetmanie wielki, wielkoduszny; Ziemska Bogini $\rightarrow$ ziemska bogini; Szlachetney Krwi $\rightarrow$ szlachetnej krwi; Wam Trzem $\rightarrow$ wam trzem), a także uporządkowano pisownię łączną i rozdzielną (Próżnoby $\rightarrow$ Próżno by; dobrzeczynienia $\rightarrow$ dobrze czynienia; Tenci $\rightarrow$ Ten ci; nie zmieniony $\rightarrow$ niezmieniony; odrobine $\rightarrow$ o drobinę; Wcale $\rightarrow W$ cale; Nad Dziadow $\rightarrow$ naddziadów). Pochylenie głoski $e$ (é) zaznaczono tylko wtedy, gdy wymagała tego dokładność rymu (dziécie - życie; bywa - powatpiéwa). Zachowano liczne dawne formy fleksyjne (sercy, Przyjm, zwiem, płci niewieści, prosiemy, rozkażem), a także spójnik jeźli. Końcówkę narzędnika liczby mnogiej -emi zastąpiono współczesną formą -ymi (Twemi $\rightarrow$ twymi). Zachowano występujące $\mathrm{w}$ dawnej polszczyźnie oboczne tematy wyrazów (nazowie, bohatyry, szczyry, balki, styrnikiem, nadgrodę, Polszcze, styr, naśledniki); część z nich objaśniano w komentarzach. Zachowano także grupę śródgłoskową -śrz- (wśrzód). Zredukowaną formę zaimka oznaczającego drugą osobę liczby pojedynczej zapisano $\mathrm{z}$ dywizem $(-\hat{c}) \mathrm{w}$ celu uwydatnienia tej struktury gramatycznej ( Wdzięcznyć $\rightarrow$ Wdzięczny-ć; daieć $\rightarrow$ daje-ć; Stawiamyć $\rightarrow$ Stawiamy-ć; Będać $\rightarrow$ Będa-ć). Ponadto skorygowano błędy druku; pomyłki te częściej występują w wydaniu Ofiary serc obywatelskich... (mcisławskiey $\rightarrow m<\dot{s}>$ cisławskiej; Xiężneyy $\rightarrow$ księżnej; Elźbiety $\rightarrow$

19 M. Chachaj, Postać kobiety-Polki $w$ dramatach historycznych Juliana Ursyna Niemcewicza, „Annales Universitatis Mariae Curie-Skłodowska. Sectio FF: Philologiae" 17 (1999), s. 96-102. 


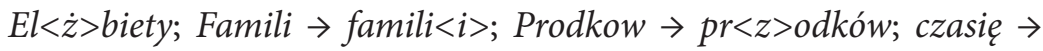
czasi $<e>$; przzymioty $\rightarrow$ przymioty; obnona $\rightarrow$ ob $<r>$ ona; dzidziczy $\rightarrow$ $d z i<e>d z i c z y$; tak tak $\rightarrow$ tak; Siostrenca $\rightarrow$ siostrz<e $>n$ nca). Odpowiednio oznaczono rozwinięte skróty, głównie formuł grzecznościowych oraz nazw urzędów i godności (Xcia $\rightarrow$ ks[ię]cia; Generała Artylleryi Lit: $\rightarrow$ generała artylerii lit[ewskiej]). Zachowano jedynie powszechnie stosowane w uproszczonej postaci formuły: Jmci, Jejmci. We francuskim epigrafie, który poprzedza pierwszy utwór, zmodernizowano pisownię, zaznaczając akcenty oraz dyftong $\propto$ (oeil $\rightarrow$ oil; ceur $\rightarrow$ cœur); interpunkcję motta pozostawiono bez zmian.

DO

JAŚNIE OŚWIECONEJ KSIĘŻNEJ JEJMOŚCI

ELŻBIETY

Z BRANICKICH SAPIEŻYNY, WOJEWODZICOWEJ $\mathrm{M}<$ Ś $>$ CISŁAWSKIEJ

W DZIEŃ IMIENIN

19 NOVEMBRIS 1784 W PRENACH

Il est facile, à la grandeur

De régner toujours, sur notre âme

Un coup d'oil gagne notre cour

Une politesse l'enflamme

[François de] Malherb[e]

[Łatwo wielkości

Panować zawsze nad naszą duszą.

Jednym spojrzeniem zdobywa nasze serce,

Grzecznością je rozpala. $]^{1}$

Szczęśliwy, kto wielkością duszy słabszych dziwi,

Szczęśliwszy, kto wejrzeniem jednym serca bierze,

Najszczęśliwszy, w kim rozum mocny ludzkość żywi.

Któż się wielkim prawdziwie nazowie w tej mierze?

Księżno, gdy się raz pierwszy widzieć Prenom dajesz, Panią serc czułych cnoty wszystkim się nam stajesz. 
Wielkość rodu, bogactwa, domu i imienia

Próżno by się siliły same sercy władać,

Rozum, mądrość, przezorność, chęć dobrze czynienia,

10 To tylko prawą wielkość może sławnie nadać.

Tej wielkości są winne serc i dusz daniny,

Ten ci bukiet twe Preny niosą w imieniny.

Owa miłość słodyczy ojczystego dymu,

Co tworzyła przesławne świata bohatyry,

15 Równa cię heroinom i Sparty, i Rzymu,

Gdzie duch obywatelski, patriotyzm szczyry.

Ten duch cnoty, gdy wlałaś w kochane swe dziécie,

Dom Sapiehów się wskrzesza i nowe ma życie.

Pięknie, gdy płci pieszczonej wdzięki uczą cnoty,

20 Piękniej, gdy rozum $\mathrm{z}$ cnotą wdzięki płci pomnaża.

Cóż, gdy z związków szczęśliwych wyjdzie owoc złoty,

A w nim cnota i sława nad przodków przeważa?

Sławie rozum z wymową gdy przydają ceny,

Wdzięczny-ć naród za posła, za starostę Preny.

25 Pierwszy w Grodnie $\left(^{*}\right)^{2}$ sejm, niegdyś po unii sławnej,

Pod marszałkiem Sapiehą stanął dziełem zgody.

Dziś znów w Grodnie wymową zrównał sławie dawnej

Sapieha książę, w jedność łącząc dwa narody

W zdaniach różnych, tak mową czynił serc odmiany!

30

Gdy słowo rzekł Sapieha, zgadzały się stany!

Cóż za czułość rozkoszna sercu wielkiej matki,

Gdy kraj cały napełnia śliczna sława syna,

Jak szczęśliwych ojczyźnie nadziei zadatki,

Gdy go naród uwielbiać z miłością poczyna.

I czyż milszy ci bukiet Preny dać zdołają,

Jak gdy sławie starosty swego hołd ten dają?

Przyjm, księżno, to, co szczerość uprzejma wyraża 
I radość ludu, pierwszy raz widząc swe pany.

Prostota wielkie dusze cieszy, nie obraża,

40

Ten hołd daje-ć z pasterzem swym lud twój poddany.

Żyj sławie, żyj ojczyźnie, synowi i wnukom,

Żyj szczęściu sług, poddanych, żyj wierze, naukom.

\section{[WOJCIECH ZACHARKIEWICZ]}

Ofiara serc obywatelskich narodu polskiego i W[ielkiego] Ks[ięstwa] Lit[ewskiego] Jaśnie Oświeconej familii książąt Ichmościów Sapiehów z okoliczności przyjazdu na sejm do Warszawy Jaśnie Wielmożnego Branickiego, hetmana wielkiego koronnego, i marszałkostwa sejmowego Jaśnie Oświeconego ks[ię]cia Jmci Sapiehy, generała artylerii lit[ewskiej], Jaśnie Oświeconej księżnej Jejmości $\mathrm{El}<\dot{\mathrm{z}}>$ biety Sapieżyny syna, a Jaśnie Wielmożnego hetmana siostrzeńca, w miesiącu grudniu roku 1788 przez wdzięcznego tej famili<i> patriotę uczyniona

\section{DO JAŚNIE WIELMOŻNEGO HETMANA W[IELKIEGO] KOR[ONNEGO]}

Dzień ten wesoły i nader nam miły,

W który hetmana nieba sprowadzily

Do tej stolicy na obrady święte.

O! Jak języki złych będą cofnięte,

Które zaoczne już zdania dawały,

Jakby go nigdy oglądać nie miały.

Patrzcież na niego, wszak ten niezmieniony,

Mówcie, czy ganny, czy ma być wielbiony?

Własność złośliwa winić bez przyczyny,

Poczciwy żadnej nie znajdzie w nim winy, 
Złość o drobinę w cudzym oku szydzi,

A w swoim balki gorszącej nie widzi.

Ten to mąż, który z cnót się samych składa,

Najszacowniejsze przymioty posiada,

15 Ten będzie szukał i ojczyzny zdrajcy,

I razem swojej zemsty z winowajcy,

Ten, co zna siebie, bardziej drugich ceni,

Drogi cnotliwej nigdy nie odmieni.

Tak jest, hetmanie wielki, wielkoduszny,

20 Masz do twej woli pretekst bardzo słuszny,

Kto zna twe myśli, ten ci daje chwały,

Do nóg ci padnie, który był zuchwały.

Ty więc, Nestorze, Achillesa płodzie,

Gdy cię walecznym zwiem w polskim narodzie,

25 Rusz twe na odzysk krajów cnych sprężyny,

Niech twoje będą wiekopomne czyny,

Wszak z tobą będzie narodu postawa,

Niech zrówna sławę przodków twa buława.

Jest twój siostrzeniec sejmowym styrnikiem,

Ty narodowych bądź wojsk przewodnikiem,

Niech Branickiego waleczności ślady

Mają Polacy za święte przykłady.

\section{DO JAŚNIE OŚWIECONEJ KSIĘŻNEJ JEJMCI SAPIEŻYNY}

Stawiamy-ć, księżno, już w sercach ołtarze,

W nich brat i z synem niech chwaleni w parze

Będą od wszystkich, niech cię wielbią ziemie Za dobre plemię.

Bo jeźli piękna rzecz rodzić się komu

W przezacnym $\mathrm{pr}<\mathrm{z}>$ odków starożytnym domu,

Ledwie się znajdzie w świecie tak ozdobna, 
Tobie podobna.

Kiedy sam Jowisz ten ci honor czyni,

Głosi przed światem, żeś ziemska bogini,

Ja mówię śmiało, choć z innych nie szydzę,

Równej nie widzę.

Masz brata wodzem i w sercu wielkiego,

$\mathrm{W}$ cale $\mathrm{w}$ tym czasi<e $>$ dla nas potrzebnego,

Ten narodowe ocali swobody

I kraj od szkody.

Syn zaś marszałek przez swe dobre rady

Niszczy ojczyzny wszelkie złe zawady,

Każdy zna, jak jest na tym sejmie czynny,

20

Bo miodopłynny.

Któż znał równego w tak słodkiej wymowie,

Wszystkich zadziwia, co on tylko powie,

Każdy przyznaje rozum bez cenzury,

Cud nad natury.

25 Jest to dla ciebie wiekopomna chwała,

Żeś tak pełnego cnót syna wydała,

Niech tysiącami rodzą się i dziatki,

I takie matki.

Mówią o tobie, skąd się w płci niewieści

Zawziął i jak się rozum męski mieści.

Myśl nie jednego z zadumieniem wzrusza

Twa wielka dusza.

Po co nam mnogość przodków wyliczacie,

Patrzcie na księżnę, dość na jednej macie,

Wstąpcie w jej ślady i wszystkie przymioty, Życie i cnoty.

U Rzymian z cnót, dzieł tę nadgrodę miano,

Że ich ojczyzny ojców nazywano,

Ale któż tobie tytuł doskonały 
Ty Polskę szczycisz krwią i twymi czyny,

Przewyższasz sercem wielkie heroiny,

Bądźże więc, z syna i z dzieł twoich rzadka,

Ojczyzny matka.

45

A gdyś jest matka bogata w przymioty,

I sama wszystkie gdy posiadasz cnoty,

Wiek ci szczęśliwszy i dłuższy niech spłynie

Nad monarchinie.

Im więcej pragnę twe wielbić zaszczyty

I cnych przymiotów poczet znamienity,

Zda się, jakobym gwiazdy wśrzód dnia słońca

Liczył bez końca.

Bo choćby wszyscy zebrali się wieszcze

Na twe pochwały, brak im będzie jeszcze,

55

Gdyż mnogość twych cnót, mówić mi się godzi, Możność przechodzi.

Więc, wielka księżno, choć samo pragnienie,

Przyjm duszą wielką już za uwielbienie,

A ja niech ciebie, gdy nie mogę pieniem,

Wielbię milczeniem.

\section{DO JAŚNIE OŚWIECONEGO KSIĘCIA JMCI SAPIEHY, MARSZAŁKA SEJMOWEGO, SIOSTRZEŃCA I SYNA}

Czczony w Polszcze, Sapieho, znany u sąsiadów,

Ćmisz sławą Lwa i Pawła, zacnych twych naddziadów.

Wdzięczna Litwo, słusznie się chlubisz twym wyborem,

Widząc, że twój marszałek idzie cnoty torem.

$5 \quad$ Lecz chociaż Litwy tylko ten mąż laską włada,

Przecież wszystkich i miłość, i serca posiada,

Równie go wielbi Litwa, równie czci Korona, 
Bo w ręku jego pewna swobód cnych ob $<\mathrm{r}>$ ona.

Niech będzie przez nas wszystkich dzień ten uwielbiany,

W którym styr przez Litwinów jemu jest oddany,

Gdyż ile kraj nasz polski szlachetnej krwi liczy,

Tyle serc w nim ten książę przychylnych dzi<e >dziczy,

I chociaż mu posągów stawiać nikt nie każe,

Nic jednak sławy jego wieczystej nie zmaże.

15 Trwaj, prosiemy, marszałku, w tak świętym zapale,

Kochaj z nami ojczyznę, bądź cnotliwym stale,

Używaj twej tak słodkiej wymowy ku sławie,

Mów prawdę, grom występki, zawstydzaj bezprawie.

Masz nas wszystkich przy sobie, rozkażem potomkom,

20 Aby cię uwielbiali, napiszemy ziomkom.

Związałeś nasze serca, wyzwól też z niewoli

Braci tu nieprzytomnych, których zawsze boli,

Że z nami nie współkują, nie patrzą na ciebie,

Ale przez nas żądają względów twych na siebie.

25 O! Jedyny w swych czynach i przymiotach panie,

Pamięć o nas, a o nich miej czułe staranie,

Wszak co zrobisz gorliwy cnotą, wspaniałością,

Będą-ć się naśledniki wypłacać miłością.

Apollo sam z muzami śpiewać będzie pienia,

Że Sapieha wart chwały do świata skończenia.

DO WSZYSTKICH RAZEM, BRATA I SIOSTRY, WUJA I MATKI, SIOSTR $<$ Z $>$ ENCA I SYNA

Doskonałość w trzech zawsze gdy osobach bywa,

Więc o dziełach ich świętych nikt nie powątpiéwa.

Stąd ów odgłos w pochwały sprawiedliwe żyzny,

Że jesteście ozdobą i światłem ojczyzny, 
$5 \quad$ Która mocą ściśniona już prawie umiera,

Jedna życia nadzieja, że się na was wspiera.

Wy dzielnością wzruszycie zwycięzców popioły,

Wam śpiewać będą chwały z narodem kościoły.

Brat z siostrą, matka $\mathrm{z}$ synem już po świecie słynie,

10 Niech kastalski na was trzech zdrój pochwał wypłynie,

By nigdy nie wysychał aż do końca świata

Dla pamiątki wieczystej matki, syna, brata.

Ta ofiara choć mała, lecz z serca wielkiego,

Niech mnie wam trzem zaleci za sługę wiecznego.

$\mathrm{W}$ [ojciech] $\mathrm{B}$ [rodzic] $\mathrm{Z}$ [acharkiewicz] $\quad \mathrm{r}$ [ejent] $\mathrm{z}$ [iemski] $\mathrm{b}$ [rzesko]k[ujawski]

Objaśnienia

DO JAŚNIE OŚWIECONEJ [...] W DZIEŃ IMIENIN 19 NOVEMBRIS $1784 \mathrm{~W}$ PRENACH

Tytuł: Preny - miejscowość usytuowana nad Niemnem na zachód od Wilna w województwie trockim Wielkiego Księstwa Litewskiego, ówcześnie siedziba starostwa, którego posesorem był Kazimierz Nestor Sapieha.

Motto - epigraf został zaczerpnięty ze sceny czwartej trzeciego aktu opery komicznej Le diable à quatre, ou la Double Métamorphose. Libretto tej kompozycji stworzył Michel-Jean Sedaine (premiera $\mathrm{w}$ roku 1756$)^{20}$. Dzieło przynajmniej raz było wystawiane na scenie warszawskiego teatru publicznego (w 1766 roku), nie wiadomo jed-

20 [M.-J.] Sedaine, Euvres choisies, t. 1, Paris 1830, s. 133. 
nak z czyją oprawą muzyczną ${ }^{21}$. W oryginale fragment ten ma nieco inną postać: „Qu’il est facile à la grandeur / D’imposer des lois à notre âme; / Un coup d'œil soumet norte cœur, / Une politesse l'enflamme"22. Trudno określić, dlaczego nieznany wierszopis błędnie przypisał motto François de Malherbe’owi. Być może przywołując go jako autora, zamierzał - stosownie do uroczystej atmosfery wykreowanej w powinszowaniu - zatrzeć związek przywołanej myśli $\mathrm{z}$ utworem komicznym, a zatem o lekkiej tonacji. Ponadto panegirysta - zapewne również w celu przystosowania motta do laudacyjnej wymowy imieninowego podarunku - dokonał korekt stylistycznych, które zmieniły wydźwięk oryginału. W tekście Sedaine’a jest bowiem mowa o tym, iż wielkości łatwo narzucić prawa (imposer des lois) naszej duszy, a także wskazuje się tam, że jednym spojrzeniem bi e r z e w posiadanie (soumet) nasze serce. Twórca zastąpił zatem określenia wyraźnie nazywające stan dominacji sformułowaniami o łagodniejszej wymowie, które wyłącznie pośrednio sygnalizują przymusowy charakter owego „panowania”. Za wskazanie źródła epigrafu serdecznie dziękuję Recenzentce.

w. 4: Une politesse - grzeczność lub uprzejmość pojmowane nie tylko jako dobre maniery, lecz przede wszystkim jako określony sposób bycia i zachowania we wspólnocie, który stanowi pokłosie bywania w świecie, a także - poświadczenie szlachetnego urodzenia.

\section{Wiersz}

w. 2: wejrzeniem - spojrzeniem.

w. 4: nazowie - nazwie.

w. 4: Któż się wielkim prawdziwie nazowie w tej mierze? - sens: kto zgodnie z prawdą określi się wielkim, znając miarę wielkości?

w. 6: Panią serc czułych cnoty - panią serc strzegących cnoty.

21 A. Żórawska-Witkowska, Muzyka na dworze i $w$ teatrze Stanisława Augusta, Warszawa 1995, s. 210.

22 [M.-J.] Sedaine, Euvres choisies..., s. 175. 
w. 11: Tej wielkości sq winne serc i dusz daniny - sens: tej wielkości podlegają daniny serc i dusz.

w. 13: miłość słodyczy ojczystego dymu - sens: miłość, którą wzbudza widok dymu komina rodzinnego dworu, a więc miłość do rodzinnych stron lub szerzej - ojczyzny. Podobną metonimią posłużył się Adam Naruszewicz w epibaterionie napisanym z okazji powrotu Adama Kazimierza Czartoryskiego do kraju w 1769 roku. Poeta nawiązał w pochwalnej wizji do wątku tułaczki odysejskiej, wprowadzając między innymi zwięzłe westchnienie Ulissesa: „[...] «O, któraż godzina / da z ojczystego ujrzeć dym komina?!»" (w. 63-64) ${ }^{23}$.

w. 18: Dom Sapiehów się wskrzesza i nowe ma życie - Kazimierz Nestor Sapieha był ówcześnie najmłodszym właścicielem Kodnia, gniazda odrębnej gałęzi litewskiego rodu.

w. 21: gdy z związków szczęśliwych wyjdzie owoc złoty - pochlebcze nawiązanie do drugiego małżeństwa Elżbiety z Branickich, która po unieważnieniu pierwszego związku (1755) wyszła za Jana Sapiehę (1756), wojewodzica mścisławskiego i głównego spadkobiercę fortuny po kanclerzu wielkim litewskim Janie Fryderyku Sapieże. Prawie nic nie wiadomo na temat krótkiego pożycia tej pary. $Z$ tego powodu w pracach poświęconych arystokratce najczęściej przywołuje się wzmiankę, którą na ten temat poczynił Marcin Matuszewicz, relacjonując spotkanie z magnatką w 1761 roku: „[...] poszła za Jana Sapiehę [...], z którym syna jednego dotychczas żyjącego miała. Dosyć hoża i miła pani. Mąż jej także barzo grzeczny i dobry pan, z tym wszystkim taką do niej miał potem awersją, że jej przy śmierci swojej widzieć nie chcial" 24 .

w. 23: Sławie rozum z wymowa gdy przydaja ceny - sens: gdy rozum i wymowa dodatkowo zwiększają wartość sławy.

w. 25: niegdyś po unii sławnej - sens: w czasie po unii sławnej.

23 A. Naruszewicz, Do ks[iąże]cia Adama Czartoryskiego, generała ziem podolskich, na powrót z cudzych krajów, w: idem, Poezje zebrane..., s. 83.

24 M. Matuszewicz, Diariusz życia mego, t. 2: 1758-1764, tekst oprac. i wstępem poprzedził B. Królikowski, komentarz Z. Zielińska, Warszawa 1986, s. 167. 
w. 25-26 i przypis anonimowego autora: odwołanie do zaszczytnego osiągnięcia jednego z członków różańskiej gałęzi litewskiej familii. Franciszek Stefan Sapieha, koniuszy litewski został w 1678 roku obrany posłem $\mathrm{z}$ województwa brzeskolitewskiego, a następnie marszałkiem sejmu, który obradował w latach 1678-1679. Nie wysunięto wówczas kontrkandydata do objęcia tego prestiżowego stanowiska. Wtedy to, po raz pierwszy od czasu zawiązania unii realnej w Lublinie w 1569 roku, a więc od momentu powołania do życia Rzeczypospolitej Obojga Narodów, miejscem zgromadzenia było Grodno. Kazimierz Nestor w 1784 roku również posłował na sejm grodzieński z województwa brzeskolitewskiego. Poza tym piastował wówczas urząd generała artylerii litewskiej (od 1773), dysponował dożywotnią dzierżawą dóbr starostwa preńskiego (przyznanie prawa w 1775, objęcie dóbr w 1782), a także mógł się poszczycić godnością starosty grodowego brzeskolitewskiego (od 1783), co dawało mu wpływ na sądy grodzkie na podległym mu terytorium.

w. 28: $d$ wa narody - szlachta polska i litewska.

w. 27-30: wbrew zapewnieniom autora o dążeniu do porozumienia książę w trakcie prac sejmu, aktywnie wspierając działania opozycjonistów przeciw zamierzeniom dworu, groził także zerwaniem obrad. Być może zatem słowa o zgodzie zgromadzonych stanów odnoszą się do daru dwunastu armat, które arystokrata obiecał przekazać wówczas litewskiej armii.

w. 31: czułość rozkoszna - wzruszenie napełniające rozkoszą.

w. 33: Jak szczęśliwych ojczyźnie nadziei zadatki - inwersja: jak ojczyźnie zadatki szczęśliwych nadziei.

w. 41: $\dot{z} y j$ [...] synowi i wnukom - Kazimierza Nestor zmarł bezpotomnie, lecz wówczas, a więc jesienią 1784 roku, jego matka mogła mieć jeszcze uzasadnione nadzieje, że w przyszłości doczeka narodzin potomków jedynaka.

w. 42: $\dot{z} y j$ wierze, naukom - nic nie wiadomo na temat działalności mecenasowskiej księżny, a ponieważ arystokratka doczekała się negatywnych ocen ze strony uczonych, których sprowadzała między innymi dla wykształcenia syna (źródłem konfliktów były zaległości w opłatach za wykonaną pracę), to należy przypuszczać, że ów brak 
informacji nie jest wynikiem opieszałości historyków. Równocześnie magnatka zapewne cieszyła się - przynajmniej w pewnych kręgach - opinią damy pobożnej. Adam Naruszewicz w pochwalnym soterionie z 1770 roku przedstawił wojewodzicową jako wzorową chrześcijankę ${ }^{25}, \mathrm{z}$ kolei ponad dekadę później bernardyn Wenanty Tyszkowski w liście dedykacyjnym skierowanym do arystokratki, poprzedzającym cykl trzynastu dialogów jego pióra, wspominał w zachowaniu księżny „wielkość cnót” i „pobożność z hojnością [...] złączone" 26 .

\section{OFIARA SERC OBYWATELSKICH [...] W MIESIĄCU GRUDNIU ROKU 1788 PRZEZ WDZIĘCZNEGO [...] PATRIOTE UCZY- NIONA}

Tytuł: Ofiara serc obywatelskich... z okoliczności przyjazdu na sejm do Warszawy Jaśnie Wielmożnego Branickiego, hetmana wielkiego koronnego - Franciszek Ksawery Branicki stanął w Warszawie 17 grudnia 1788 roku; ...i marszałkostwa sejmowego Jaśnie Oświeconego ks[ię]cia Jmci Sapiehy, generała artylerii lit[ewskiej]... Kazimierz Nestor Sapieha został obrany marszałkiem konfederacji litewskiej sejmu 7 października 1788 roku, a więc w dzień po otwarciu obrad; ...w miesiącu grudniu roku 1788... uczyniona - wskazanie miesięcznej (a nie dziennej) daty złożenia wierszowanego daru jest być może sygnałem, że panegiryk powstał przed przybyciem hetmana do stolicy, gdy jeszcze nie wiedziano, kiedy dokładnie nastąpi przyjazd.

25 A. Naruszewicz, Powinszowanie księżnie Elżbiecie..., s. 170-172 (utwór), s. 231 (komentarz edytorski), s. 312-313 (objaśnienia).

26 W. Tyszkowski, Jaśnie Oświeconej księżnie Jmci Elżbiecie z Branickich księżnie Sapieżynie, wojewodzicowej mścisławskiej, pani i dobrodzice, w: idem, Teatrum myśli albo zdań $z$ soba walczących $w$ materiach siłu rozróżnionych religii szukajacym prawdy otworzone, przez siedmiu aktorów zagajone. Tomik o miejscach osobliwych razem $z$ światem całym stworzonych do ukarania wszystkich grzesznych, od samegoż Stwórcy wyznaczonych, Lwów 1780, k. [A 3 ]v. 


\section{DO JAŚNIE WIELMOŻNEGO HETMANA W[IELKIEGO] KOR[ONNEGO]}

w. 4-12: nawiązanie do zainteresowania i nieprzychylnych ocen części opinii publicznej, którą oburzał ówczesny pobyt Branickiego, naczelnego zwierzchnika wojsk Korony, u boku Griegorija Potiomkina, głównodowodzącego wojsk carskich, pod Oczakowem. Jak sugeruje poeta, niektórzy z oponentów hetmana mieli rozpowszechniać złośliwe plotki, że dostojnik w ogóle nie przyjedzie do stolicy, ignorując prace sejmu.

w. 8: ganny - ganiony.

w. 11: o drobine [...] szydzi - sens: z powodu błahostki drwi.

w. 12: balki - belki.

w. 11-12: aluzja do jednego z moralnych zaleceń, które Jezus przekazał w trakcie Kazania na Górze, ujmując je w ramy czytelnej metafory: „Czemu to widzisz drzazgę w oku swego brata, a belki we własnym oku nie dostrzegasz?” (Mt 7,3) ${ }^{27}$.

w. 20: Masz do twej woli pretekst bardzo słuszny - sens: masz słuszny powód działania zgodnie z twoją wolą.

w. 23: Achillesa płodzie - synem Achillesa (i królewny Deidamei, jego kochanki) był Neoptolemos zwany także Pyrrosem; tu mowa o człowieku walecznym, mężnym; być może jest to również pochlebcze przypomnienie ojca hetmana, Piotra Franciszka Branickiego (zm. w 1762), kasztelana bracławskiego. Skądinąd nic nie wiadomo na temat jego wojskowych sukcesów, choć piastował on urząd chorążego halickiego.

w. 24: Gdy cię walecznym zwiem w polskim narodzie - nawiązanie do reputacji Branickiego, który niemal od początku swej działalności publicznej był związany z wojskiem. Najpierw został pułkownikiem chorągwi pancernej (1757), szybko też znalazł się u boku królewi-

${ }^{27}$ Pismo Święte Starego i Nowego Testamentu w przekładzie z języków oryginalnych, oprac. zespół biblistów polskich z inicjatywy benedyktynów tynieckich, wyd. 3 popr., Poznań 1982, s. 1131. 
cza Karola Chrystiana Wettyna (syna króla Augusta III), a następnie odznaczył się w kilku potyczkach wojny siedmioletniej w wojsku austriackim, rosyjskim i francuskim (1757-1758, 1759-1760). Później trwale związał się ze stolnikiem wielkim litewskim Stanisławem Antonim Poniatowskim (poznali się w 1758 roku w Petersburgu), a dzięki zamachowi stanu i objęciu tronu przez patrona został uhonorowany stanowiskiem generała-porucznika w armii koronnej i generała artylerii litewskiej (1764). Ukoronowaniem wojskowej kariery Branickiego były - przyznane mu decyzją monarchy - godności ministerialne: hetmana polnego koronnego (1773) i hetmana wielkiego koronnego (1774).

w. 25: odzysk krajów cnych - odzyskanie ziem utraconych w trakcie pierwszego rozbioru.

w. 27: narodu postawa - poglądy i zachowania członków narodu.

w. 28: niech zrówna sławe przodków - stosunkowo niewiele wiadomo na temat osiągnięć przodków Franciszka Ksawerego Branickiego. Jego pradziadek, Piotr był rotmistrzem wojsk koronnych, natomiast dziadek, Józef (zm. w 1735) walczył w wojnie szwedzkiej po stronie Augusta II (1702-1709), a także zyskał godność porucznika chorągwi husarskiej oraz kasztelana łęczyckiego. Następnie został pułkownikiem wojsk koronnych (1715), jak rówież piastował urzędy stolnika buskiego, a następnie kasztelana halickiego. Wiadomo także, że pełnił funkcję marszałka wojsk konfederacji tarnogrodzkiej, do której przystąpił po rozczarowaniu poczynaniami wojsk saskich w trakcie wielkiej wojny północnej.

w. 31-32: waleczności ślady - kolejna aluzja do kariery wojskowej Branickiego. Nawiązywanie do męstwa hetmana było jednak dość ryzykowne, gdyż dostojnik był również znany z pacyfikowania zrywu barskiego u boku wojsk carskich (1768-1772), co zresztą przypomnieli paszkwilanci doby Sejmu Wielkiego. 


\section{DO JAŚNIE OŚWIECONEJ KSIĘŻNEJ JEJMCI SAPIEŻYNY}

Tytuł: Sapieżyny - w druku: Sapiezyney, zmieniono formę dopełniacza występującą w tytule drugiej części zbioru, gdyż w tytule całego cyklu została wprowadzona inna postać dopełniacza: Sapieżyny.

w. 5-8: pochwała koligacji rodowych arystokratki, która pochodziła z domu Branickich herbu Korczak, a tytuł książęcy i znaczący majątek zawdzięczała małżeństwom z przedstawicielami rodu Sapiehów: Janem Józefem Kalasantym, wojewodzicem smoleńskim z różańskiej linii litewskiego domu (1753-1755) i Janem, wojewodzicem mścisławskim z kodeńskiej gałęzi familii (1756-1757).

w. $14:$ cale - całkowicie.

w. 15-16: Ten narodowe ocali swobody / I kraj od szkody - skrótowe ujęcie sylwetki Franciszka Ksawerego Branickiego nawiązujące do programu politycznego hetmana, który wielokrotnie przedstawiał się jako obrońca swobód obywateli rzekomo zagrożonych poczynaniami króla Stanisława Augusta.

w. 20: miodopłynny - odznaczający się słodką i wdzięczną wymową.

w. 23: rozum bez cenzury - rozum bez krytyki, która (zgodnie z pochwalnym przekazem) w odniesieniu do krasomówczych zdolności księcia jest całkowicie nieuzasadniona.

w. 17-24: pochwała talentu oratorskiego i wzmożonej aktywności poselskiej Kazimierza Nestora Sapiehy, który w czasach Sejmu Wielkiego zasłynął perfekcyjnym opanowaniem warsztatu mówcy, często demonstrując swe możliwości. Jak wskazywano, w trakcie czteroletnich obrad marszałek zbierał głos ponad siedemset razy. $Z$ tego powodu w ówczesnych wierszowanych laudacjach często eksponowano ten element portretu księcia.

w. 30: Zawziął [...] się - wziął początek, zakorzenił się.

w. 37-38: U Rzymian $z$ cnót, dzieł tę nadgrodę miano, / Że ich ojczyzny ojców nazywano - nawiązanie do obyczaju starożytnych Rzymian wprowadzonego w czasach schyłku republiki, gdy senat rozpoczął nadawać obywatelom szczególnie zasłużonym dla wspólnoty 
zaszczytny tytuł ojca ojczyzny (łac. Pater Patriae). Pierwszą osobą uhonorowaną w ten sposób był Cyceron.

w. 41: twymi czyny - aluzja do politycznej aktywności wojewodzicowej, która od początku panowania Stanisława Augusta znalazła się na dworze nowego władcy, wspierając jego politykę, a także zyskując korzyści majątkowe i nadania dla krewnych i stronników. Z czasem, wraz z narastaniem konfliktu między królem a bratem (począwszy od nadania mu buławy wielkiej i starostwa białocerkiewskiego w 1774), wojewodzicowa zaczęła stopniowo oddalać się od monarchy. Bez względu na utratę dawnych wpływów wciąż aktywnie uczestniczyła w życiu publicznym, szczególnie pomagając przedsięwzięciom syna i brata.

w. 43-44: Bądźże więc [...] / Ojczyzny matka - nawiązanie do tytułu Mater Patriae, który za rządów Tyberiusza (14-37 n.e.) miał być nadany przez senat Liwii Druzylli, wdowie po Oktawianie Auguście i matce ówczesnego cesarza. Pomysł ten ostatecznie nie uzyskał aprobaty władcy (por. objaśnienie do w. 37-38).

w. 47-48: Wiek ci szczęśliwszy i dłuższy niech splynie / Nad monarchinie - być może aluzja do długich rządów dwóch władczyń i zarazem imienniczek wojewodzicowej: królowej angielskiej i irlandzkiej Elżbiety I Tudor, która panowała w latach 1558-1603, i carycy Elżbiety I Romanowej, zasiadającej na tronie rosyjskim w latach 1741-1762.

DO JAŚNIE OŚWIECONEGO KSIĘCIA JMCI SAPIEHY, MARSZAŁKA SEJMOWEGO, SIOSTRZEŃCA I SYNA

w. 2: Ćmisz - przyćmiewasz; Lwa i Pawła - Lew Bazyli Sapieha (1557-1633), wojewoda wileński, który piastował kolejno urząd kanclerza i hetmana wielkiego litewskiego, Paweł Jan Sapieha (16091665), wojewoda wileński i witebski, hetman wielki koronny; obydwaj dostojnicy przez wiele lat byli aktywni na scenie publicznej, co sprawiło, że należeli do grona najbardziej wpływowych i znanych statystów w historii litewskiego rodu; naddziadów - pradziadów, przodków; wskazani przez Zacharkiewicza arystokraci byli przed- 
stawicielami starszej, tak zwanej różańskiej linii rodu, natomiast Kazimierz Nestor pochodził z młodszej gałęzi familii, nazywanej kodeńską.

w. 21-24, 26 - wyrażone w formie próśb o pamięć i wyzwolenie $\mathrm{z}$ niewoli nawiązanie do trudnego losu obywateli zakordonowanych od czasów pierwszego rozbioru.

w. 23: z nami nie współkuja - sens: nie uczestniczą z nami w życiu wspólnoty wolnych obywateli, których przedstawiciele obradują na sejmach i sejmikach.

w. 28: naśledniki - naśladowcy; tu mowa o kolejnych pokoleniach wolnych obywateli, którzy będą naśladować chwalebne poczynania księcia, do podjęcia których zachęca poeta.

DO WSZYSTKICH RAZEM, BRATA I SIOSTRY, WUJA I MATKI, SIOSTRZEŃCA I SYNA

w. 1: Doskonałość w trzech zawsze gdy osobach bywa - inwersja: gdy doskonałość zawsze bywa w trzech osobach.

w. 1-2: pochlebne nawiązanie do zasady pisarskiej, często przywoływanej $\mathrm{w}$ formie łacińskiej sentencji omne trinum perfectum („wszystko co potrójne [jest] doskonałe”); zarazem pośrednie, choć czytelne skojarzenie trojga chwalonych osobistości z Trójcą Świętą.

w. 4-5: ojczyzny, / Która moca ściśniona już prawie umiera - skrótowe nawiązanie do trudnej sytuacji Rzeczypospolitej po pierwszym rozbiorze.

w. 10: kastalski [...] zdrój pochwał - strumień wypływający ze źródła w Delfach, które zostało poświęcone Muzom oraz ich opiekunowi Apollinowi, a usytuowane było u stóp Parnasu; tu: źródło natchnienia, które doprowadzi do stworzenia laudacji na cześć opiewanych arystokratów. 


\section{Bibliografia}

Chachaj M., Postać kobiety-Polki w dramatach historycznych Juliana Ursyna Niemcewicza, „Annales Universitatis Mariae Curie-Skłodowska. Sectio FF: Philologiae” 17 (1999).

Czeppe M., Sapieżyna z Branickich Elżbieta, w: Polski słownik biograficzny, t. 35, Warszawa 1994, s. 163-167.

Dąbrowski S.P., Portrety Elżbiety z Branickich Sapieżyny w paszkwilach obyczajowych i politycznych, w: Codzienność i niecodzienność oświeconych, [cz.] 2: W rezydencji, w podróży i na scenie publicznej, red. B. Mazurkowa, z udziałem M. Marcinkowskiej i S.P. Dąbrowskiego, Katowice 2013.

Dąbrowski S.P., Uwagi o „Porankach kodeńskich” Ignacego Potockiego, „Wschodni Rocznik Humanistyczny” 10 (2014).

„Gazeta Warszawska” 102 (1788).

Kaleta R., O twórczości satyrycznej Franciszka Zabłockiego w okresie Sejmu Czteroletniego, w: idem, Oświeceni i sentymentalni. Studia nad literatura i życiem $w$ Polsce w okresie trzech rozbiorów, Wrocław 1971.

Kądziela Ł., Sapieha Kazimierz Nestor, w: Polski słownik biograficzny, t. 35, Warszawa 1994.

Kostkiewiczowa T., Oda, w: Słownik literatury polskiego oświecenia, red. T. Kostkiewiczowa, wyd. 4, Wrocław 2006.

Maksimowicz K., Poezja polityczna a Sejm Czteroletni, Gdańsk 2000.

Maksimowicz K., Portretowy soterion i jego kulisy: Powinszowanie księżnie Elżbiecie z Branickich Sapieżyn<ie> szczęśliwego do zdrowia powrócenia, w: Czytanie Naruszewicza, [cz.] 1, red. B. Wolska, T. Kostkiewiczowa, B. Mazurkowa, Warszawa 2015.

Maksimowicz K., Sposoby rozpowszechniania wierszy polityczno-okolicznościowych $w$ dobie Sejmu Wielkiego i konfederacji targowickiej, w: Byle w ludziach światło było... Ksiega pamiątkowa ku czci Profesora Wacława Woźnowskiego w dziesiąta rocznicę jego śmierci, red. G. Zając, Kraków 2012.

Mazurkowa B., Problem i przejawy panegiryzmu w poezji okolicznościowej drugiej połowy XVIII wieku, w: Panegiryk jako element życia literackiego doby staropolskiej i oświeceniowej, red. M. Sulejewicz-Nowicka, Z. Gruszka, wstęp M. Wichowa, Łódź 2013.

Naruszewicz A., Poezje zebrane, t. 1, wyd. B. Wolska, Warszawa 2005.

Niedźwiedź J., Nieśmiertelne teatra sławy. Teoria i praktyka twórczości panegirycznej na Litwie w XVII i XVIII w., Kraków 2003.

Norkowska A., Wizerunki władcy. Stanisław August Poniatowski w poezji okolicznościowej (1764-1795), Kraków 2006. 
Sapieżyna E. z Branickich do Okęckiego A.O., Olita, 18 listopada 1784, w: Korrespondenz der Fürsten Sapieha. 1709-1798, Archiwum Główne Akt Dawnych, Archiwum Komierowskich, rkps 12/11.

Wiersze imieninowe poetów $z$ drugiej połowy XVIII wieku, wstęp, wybór i oprac.

B. Wolska, B. Mazurkowa, T. Chachulski, Warszawa 2011.

Woźnowski W., Pamflet obyczajowy w czasach Stanisława Augusta, Wrocław 1973.

\section{(Footnotes)}

1 Tłumaczenie francuskiego motta - S.P.D.

2 Przypis anonimowego autora: $\left.{ }^{*}\right) \mathrm{W}$ roku 1678 pierwszy sejm w Grodnie doszedł pod laską Franciszka Sapiehy, koniuszego litewskiego. Teraz w roku 1784 na sejm w Grodnie [został wybrany - S.P.D.] poseł Nestor Kazimierz książę Sapieha, generał artylerii Wielkiego Księstwa Litewskiego, sądowy brzeski i preński starosta. 